\title{
Armin Kohnle - Thomas Krzenck (Hgg.), unter Mitarbeit von Friedmann Richter und Christiane Domtera-Schleichardt, Johannes Hus deutsch,
} Evangelische Verlagsanstalt Leipzig 2017, XXXII + 730 ss., ISBN 978-3-374-04165-7

Objemný svazek přináší vyvážený výběr 37 děl Jana Husa z let 1403-1415 v novém nebo revidovaném německém překladu. Postihuje všechny žánry jeho tvorby (univerzitní útvary, kazatelské dílo, teologické práce, kontroverze, obrany i korespondenci) a dokumentuje klíčové momenty jeho života.

Iniciátoři tohoto podniku nejsou v českém prostředí neznámi. Armin Kohnle, profesor teologické fakulty v Lipsku, se zabývá reformací v Německu, spolupracuje na kritickém vydání spisů a korespondence Tomáše Müntzera a je autorem publikací o Lutherovi i dalších významných osobnostech včetně Husa. ${ }^{1} \mathrm{~V}$ daném svazku měl na starosti texty latinské. Thomas Krzenck, který zajišt’oval překlady z češtiny, se věnuje dlouhodobě přímo bohemikálním tématům. V několika studiích pojednal o testamentech z českých měst. V poslední době pak zaměřil svoji pozornost na osobnost Jana Husa, o jehož životě a učení vydal popularizující monografii pro německé publikum. ${ }^{2}$ Ke stejnému prostředí se obrací i tento nový svazek, který byl zařazen do volné ediční série Werkausgaben der großen Reformatoren. Byly v ní již vydány tři svazky německých děl Martina Luthera s převodem do dnešní němčiny, tři svazky jeho latinských děl s paralelním německým překladem, čtyři svazky děl Philippa Melanchthona v německém překladu a tři svazky kritické edice díla Thomase Müntzera. Hus tak byl zařazen do společnosti nejvýznamnějších myslitelů evropské reformace.

Svazek otevírá vstupní studie, která informuje o životě, teologickém myšlení a procesu Jana Husa. Jejími autory jsou hlavní vydavatelé svazku. Autoři vycházejí z německé i české literatury, opírají se též o zcela novou produkci; vedle zmíněné publikace samotného Krzencka je to např. německá monografie P. Soukupa, ale i nedávno česky vydaná syntéza Husitské století. Druhá část předmluvy pojednává o dosavadním stavu zpřístupňování Husových děl a o starších překladech, a to od závěru 15. stol. až do současnosti.

Historie uveřejňování Husových textů tiskem začíná právě překladem do dolní němčiny (1481 v Lübecku) a pokračuje reformačními tisky 16. století. České prostředí zpočátku neprojevilo tak výrazný zájem. Německé překlady mají tedy dlouhou tradici, kterou utvrdilo přijetí Husa mezi nejvýznamnější osobnosti evropské reformace. Toto „objevení“ Husa německými evangelíky napomohlo k zachování některých Husových děl do dnešní

1 Armin KoHnle, Luther, Calvin und die anderen. Die Reformation und ihre Folgen, Leipzig 2016; TÝž, Martin Luther. Reformator - Ketzer - Ehemann, Leipzig - Berlin 2015; TÝž, Vorreformator, Reformator vor der Reformation, Wegbereiter oder Vorläufer Luthers? Ein Beitrag zum Johannes-Hus-Gedenken 2015, in: Luther. Zeitschrift der Luther-Gesellschaft 2/2016, s. 75-89; TÝŽ, Martin Luther, Johannes Hus und die hussitische Tradition in Sachsen, in: Uwe Fiedler - Hendrik Thoß - Enno Bünz (Hgg.), Des Himmels Fundgrube. Chemnitz und das sächsisch-böhmische Gebirge im 15. Jahrhundert (Ausstellung 3. Oktober 2012 bis 20. Januar 2013), Chemnitz 2012, s. 175-187.

2 Thomas KRZENCK, Johannes Hus: Theologe, Kirchenreformer, Märtyrer, Zürich 2011. 
doby a $\mathrm{k}$ podtržení významu českého reformátora. Přehled starších vydání Husových děl je př́ispěvkem $\mathrm{k}$ dosud zanedbanému zpracování tohoto tématu. Nová vlna zájmu o Husovo dílo přichází v 19. století. Hus se stává nejen předmětem uctívání jako český vlastenec, ale je i znova ceněným autorem německého evangelického prostředí. Autoři úvodu registrují celou řadu drobných i větších vydání německých překladů jeho děl i korespondence. Tento záslužný přehled je vedle vlastního vydání textů cennou součástí svazku.

Recenzované vydání německého překladu vybraných děl Jana Husa se snaží zaplnit mezeru v nabídce s ohledem na to, že od posledního vydání německého převodu uplynulo (s jedinou drobnější výjimkou) již 40 let. Obrací se k širší čtenářské obci, nečiní si tudíž ambice uspokojit po ediční stránce odborné publikum. Vydavatelé se př̀i výběru textů snažili dokumentovat vývoj teologického myšlení Jana Husa, nabídnout dokumenty důležité pro jeho soudní proces a ukázat šíri literárních žánrů, které Husovo dílo obsahuje. Stranou ponechali texty, které by svým vyhraněně učeneckým charakterem odradily čtenáře. Překlady většinou vycházely z již existujících převodů, ale všude bylo přihlédnuto i $\mathrm{k}$ originálnímu znění.

Textová část obsahuje jak nejznámější Husova díla, tak další důležité, ale méně zpopularizované dokumenty. Do výběru se dostala např. první obžaloba Husa ze strany pražského kléru (1408) a odpověd’ na ni. Husovo rektorské období zastupuje jeho řeč z 3. 12. 1409, pronesená při výroční slavnosti k úmrtí zakladatele univerzity, Karla IV. Vypočítávat nemůžeme jednotlivá kázání vč. synodálního, traktáty, výklady, kvestie, polemiky, další obvinění a žalobní artikule. Nabízí se také Husovo odvolání ke Kristu z roku 1412, jímž se definitivně rozešel s oficiální církví, nebo vyhlášení exkomunikace arcibiskupem. Nejrozsáhlejší text představuje spis $\mathrm{O}$ církvi - De ecclesia (1413), který je přeložen do němčiny v úplnosti poprvé (s. 351-572). Nechybí ani znění Zikmundova glejtu, který měl Husa ochránit při cestě na koncil. Osobní rovinu zastupují vybrané dopisy z pražského období i z kostnického vězení. Závěrečné drama popisuje zpráva Petra z Mladoňovic o procesu a odsouzení Husa v Kostnici (1415), z níž je do svazku pojata právě pasáž věnovaná mučednické smrti.

Na nových překladech z latiny i češtiny se podílelo kromě vydavatelů dalších 14 překladatelů. Předlohy pro překlad jsou evidovány u každého textu v záhlaví, kde je $\mathrm{k}$ dispozici také výklad o okolnostech vzniku díla a jeho obsahu či významu.

Orientaci méně zkušeného uživatele zajišt’uje chronologická tabulka. Svazek je vybaven bibliografií, ale pouze zkráceně citované literatury, a jmenným rejstř́kem s drobnými nepřesnostmi v českých jménech. Ilustrační složka je sestavena z 18 reprodukcí. Objevují se zde Husovy grafické portréty i ukázky některých jeho děl. Obrazová složka je však jen doprovodná a kvalita reprodukcí není vysoká.

Vydání výboru z díla Jana Husa v německém překladu je bezpochyby záslužný čin, který může napomoci popularizaci českého reformátora v německém prostředí. Hus sice od dob reformace patř́ do rodiny evropských reformátorů a byl ctěn jejími představiteli, přesto však dnešní znalost Husa mezi širši německou veřejností neodpovídá tomuto postavení, na což T. Krzenck poukázal i v tomto časopise. ${ }^{3}$

Blanka Zilynská doi: $10.14712 / 23365730.2019 .11$

3 Thomas Krzenck, Die aktuelle Popularisierung des Hus-Bildes in Deutschland, AUC-HUCP 53/1, 2013, s. $69-78$. 